\title{
Dohle Body Measurement
}

National Cancer Institute

\section{Source}

National Cancer Institute. Dohle Body Measurement. NCI Thesaurus. Code C74610.

The determination of the number of Dohle bodies present in a sample. 